\title{
The Influence of Knowledge Management Uses on Total Quality Management Practices in Commercial Banks of Jordan
}

\author{
Bader Obeidat $^{1}$, Lama Hashem ${ }^{1} \&$ Ra'ed Masa' deh $^{2}$ \\ ${ }^{1}$ Department of Business Management, School of Business, The University of Jordan, Amman, Jordan \\ ${ }^{2}$ Department of Management Information Systems, School of Business, The University of Jordan, Amman, Jordan \\ Correspondence: Bader Obeidat, Department of Business Management, School of Business, The University of \\ Jordan, Amman, Jordan. E-mail: b.obeidat@ju.edu.jo
}

Received: March 16, 2018

Accepted: September 20, 2018

Online Published: October 29, 2018

doi:10.5539/mas.v12n11p1

URL: https://doi.org/10.5539/mas.v12n11p1

\begin{abstract}
This study examines the influence of knowledge management uses on total quality management practices in commercial banks of Jordan.A quantitative research design, using regression analysis was applied in this study and a total of 250 valid returns were obtained through a questionnaire distributed to the employees of commercial banks in Jordan. Knowledge management uses was adopted as an independent variable with four subgroups: knowledge acquisition, knowledge storage, knowledge transfer and knowledge application. Total quality management practices were adopted as dependent variable with five subgroups: top management support, employee's involvement, continuous improvement, customer focus, and data driven decision management. The results show that knowledge management uses significantly affects total quality management practices at three of its dimensions (knowledge acquisition, knowledge storage, and knowledge transfer) but it showed that no effect on knowledge application. The implications of this study are discussed at the end of this paper.
\end{abstract}

Keywords: knowledge management, knowledge management uses, total quality management, total quality management practices, developing countries, commercial banks, Jordan

\section{Introduction}

Knowledge management is an idea that covers a set of approaches and practices in order to generate, save and spread knowledge and practice within the business (Loria, 2008; Obeidat et al., 2017; Abualoush et al., 2018a, 2018b). There are no clear and exact ways to clarify how business should work with knowledge management. Consequently, every business is unique by the resources that it exists in a definite context, having its workers, its set of clients, its own market and its own competitors (Masa'deh et al., 2013a, 2013b; 2015a, 2015b, 2015c; Khalayleh et al., 2017). When leaders of a society want to reflect the idea of knowledge management, they must develop precise policies in accordance with that idea and provide the staff with adequate needed capitals. However, the leaders can neither control the course of the knowledge nor control to what degree they are following these policies (Al-Syaidh \& Al-Zu'bi, 2014; AL-Syaidh et al., 2016). The only thing they can do is to inspire the workers to follow the selected strategies or encourage them to self-organize and how they should work with knowledge management (Danish et al. 2014). There is no single path to achieve total quality within an organization. There are no hard and fast rules to follow to become a world class company. The only constants are basic guidelines, that, when followed, lead to success. This is because all organizations have their own cultures, people, and technologies. What may work well for one company will not necessarily work for another (Pekar, 2005; Al Azmi et al., 2012; Obeidat et al., 2012; Shannak \& Obeidat, 2012).

To increase competitive rewards, knowledge management and how administrations release the practices expanded in projects are critical topics for commercial banks nowadays. Commercial banks, especially, those which are project-based companies have to gain by considering knowledge management strategies in their organization (Montes et al., 2003). Much of the literature has focused on what should companies in hiring consultants do in order to confirm that knowledge stays in the organization. Slight attention has been given in how do commercial banks work with knowledge management activities and their acquired knowledge from projects. Because of the sufficiency in resources and the dynamic and flexible nature of small businesses; commercial Banks make it even more special (Kaynak, 2003; Mondy, 2013). 
Commercial banks are more able to dedicate resources for knowledge management, and to build total quality management. Commercial Banks rely on gathering, processing, analyzing and providing information in order to meet the needs of customers. Banks were among the earliest adopters of automated information processing technology (Tang, 2006; Kateb et al., 2015; Hassouna et al., 2015; Masa'deh et al., 2018). Banks in the Jordanian sector have adapted total quality management to enhance the value of their banks, financially and socially, and to increase Return on Equity in order to become more reasonable in national and regional banking markets (Abu Baker, 2013; Obiedat et al., 2016). The banks also have provided banking services of high quality to trade and corporate customers, which meet purchaser's needs and surpass their anticipations, in line with the latest progresses in international financial and banking markets.

This study specifically aims to determine the effect of knowledge management uses on total quality management practices in the commercial banks in Jordan. To the best of the authors' knowledge, there are few studies that investigate effect of knowledge management uses on total quality management practices (e.g. Ju et al., 2006; Honarpour et al., 2012) and this study is the first to be tested in the commercial banks in Jordan which highlight the importance of conducting such a study.

\section{Literature Review}

The theoretical framework for this study is drawn from literature which forces mainly on two relevant areas: knowledge management and total quality management.

\subsection{Knowledge Management (KM)}

Knowledge management discusses a methodical and integrative procedure that helps organizations to find, organize, allocate and transfer important evidence, knowledge, and expertise which is essential for actions such as problem resolving, self-motivated learning, strategic planning, and decision-making to accomplish the goals of the organization (Gupta et al. 2000; Lawson 2013; Danish et al. 2014). The following Knowledge ManagementUses are considered to be the most important uses (knowledge acquisition, knowledge storage, knowledge transfer and knowledge application (Hajir et al., 2014).

\subsubsection{Knowledge Acquisition}

Ractham (2012) defined knowledge acquisition as the process of the development and creation of insight, skill and relationships. For knowledge to be acquired there should be willingness and ability of a recipient to acquire and use knowledge which is crucial elements (Gupta, 2000). During the process of knowledge acquisition, it is important that both source and recipient should be willing to share. There are five motivational drivers that should be taken into consideration: attitude towards knowledge sharing, cost and benefit, subjective norms and organizational climate and perceived value of knowledge (Ford \& Staples, 2010; Al-dalahmeh et al., 2018). Knowledge acquisition envisages learning from others through interaction between recipient and source. Nonaka \& Takeuchi (2015) indicate that the SECI (socialization, externalization, combination, and internalization) and models play important roles in knowledge acquisition through interaction and collaboration with other individual systems.

\subsubsection{Knowledge Storage}

Stein \& Zwass (2005) have highlighted that storage and retrieval of organizational knowledge are referred as administrative memory which includes knowledge residing in numerous form such as written records, documented managerial policies and measures, and organized knowledge stored in database, data warehouse or other business intelligence tools. So knowledge storage is the process of recognizing new information as relevant and essential for current and future use and storage it in reasonable forms so that anyone in the organization can access it (Alkandari et al., 2017).

\subsubsection{Knowledge Transfer}

Knowledge transfer is the knowledge wherever the data recipient acquires identical data because the data supplied and internalizes the data to create his/her new data (Krogh \&Roos, 1995).The basic framework needed to research information transfer among a corporation involves three areas of interest: the information characteristics, the activities of information transfer, and also the actual transfer performance (Cummings, 2002; Young, 2013). Information transfer is that the sensible drawback of transferring information from one a part of the organization to a different. Like information management, information transfer seeks to arrange, create, capture or distribute information and guarantee its availableness for future users (Fotopoulos \& Psomas, 2010).

\subsubsection{Knowledge Application}

Knowledge application or reuse to decision-making processes, related to business strategy, task implementations, 
service delivery, and organizational performance and effectiveness. Knowledge application processes are those processes oriented toward the actual use of knowledge (Gold et al., 2011; Pacharapha \& Vathanophas, 2012). Wiig (2007) noted that the value of knowledge assets is realized when the assets are used to create products or deliver services, or when they are sold or traded for value. Knowledge application is the ability of employees to use knowledge for the purpose of creating frameworks for solving problems and dealing with challenges in the organization. It is also the actual use of knowledge that has been captured or created and put into the KM cycle and also for the practical usage in the banking forms according to financial real application used in the real banking and business situations.

\subsection{Total Quality Management (TQM)}

Total quality management is defined as "a management approach of an organization, centered on quality, based on participation of all members and aimed at long-term success through customer satisfaction, and benefits to all members of the organization and the society"(ISO 8402:1994). TQM is a constant procedure of development for individuals, and the whole organization. Commercial banks yield a product that is intangible. Usually, the completed product cannot be seen or touched; rather, it is experienced (Wang et al., 2012).

In this research, the TQM practices that were selected for banking sector are: top management support, employee's involvement, continuous improvement, customer focus and data driven decision management. These practices have been identified as the key practices of TQM in service industries, and in the promotion of service quality (Sweis et al., 2013, p. 274).

\subsubsection{Top Management Support}

The importance of top management support has long been documented in the previous studies (Young \& Jordan, 2008). However, consultants and researchers alike have absorbed their courtesy. Prescriptions for top management support are not well established. Some impose very challenging requirements for top management resources simply to improve technical quality or user happiness, goals of little direct interest to top managers. Other preparations for communication, enthusiasm, involvement and contribution appear to be little more than exhortation. Top management support is generally endorsed as being inherently good but there is clear indication that too much top management support can be dysfunctional and lead to failure. Projects can succeed without following the general prescriptions for top management support and others can fail while following all the common prescriptions. As a result, the advice for top managers lacks trustworthiness. However, few would distrust the need for top management support and top management support is consistently recognized as a critical success factor. The problem is that current preparations are practitioner-led and mantra-like in their call for top management support. Top managers have the freedom to provide or withhold their funding, but current instructions are failing to have any important effect on their behavior.

\subsubsection{Employee's Involvement}

Colleages (2006) found no provision for the idea that the mere attendance of employee participation and contribution is related with positive employee perceptions of participation practices. It was also recommended by them that the quantity and mix of practices is the key matter in the participation and commitment relation. Research indicates that participation is not usually needed to gain commitment toward objectives, but having employee participation in the planning can be a current means of development commitment with the organization. Participation can be mainly helpful in emerging plans for applying goal. For these reasons, managers often include assistants in goal setting and in the subsequent planning of how to attain the goal. It is observed that employee's promise to the organization is strong among those whose leaders allow them to contribute in decision making (AlHarrasi\& AL-Lozi, 2015; AlHarrasiet al.., 2016; Darawsheh et al., 2016). The need for employees to be more complicated in decisions that affect their work has been a center of argument in current management issues (Hales, 2010).

\subsubsection{Continuous Improvement}

Continuous improvement is a quality philosophy which assumes that further improvements are always possible and that processes should be continuously re-evaluated and improvements implemented (Juergensen, 2005). It is also the process of seeking small improvements in processes and products, with the objective of increasing quality and reducing waste. The belief that an organization must constantly measure the effectiveness of its processes and strive to meet more difficult objectives to satisfy its customers also constitutes continuous improvement. Continuous improvement $(\mathrm{CI})$ can be considered an ongoing effort to improve products, services or processes. These efforts can seek "incremental" improvement over time or "breakthrough" improvement all at once (Bhuiyan \& Baghel, 2005, p. 761). CI's importance manifests itself in terms of the role it plays in quality improvement, 
customer satisfaction, employee engagement and productivity. Continuous Improvement is essentially a quality journey that is never ending (Oakland, 2007) and its main emphasis per Deming's teachings, lies in never accepting that the way business operates today is the best way, even in the face of profitability. Continuous Improvement in context of Kaizen means improving performance in many small, incremental steps. In Japan, continuous improvement is called kaizen. The word means continuous improvement, involving everyone in an organization. $\mathrm{CI}$ is a philosophy that Deming described simply as consisting of "Improvement initiatives that increase successes and reduce failures" (Juergensen, 2005, p .761).

\subsubsection{Customer Focus}

Retaining customers and attracting them has constituted one of the toughest and most challenging activities of financial institutions in most developing countries like Nigeria (Banabo \& Koroye, 2011). Among the litany of problems faced by financial institutions, key operate in a highly competitive banking industry, hence the consistently strategies on different forms of sales promotion strategies to attract depositors as well as incur huge cost in training and retraining personnel for more efficient service delivery. This is a result of the competitiveness of the industry and the struggle for survival of banks especially in the face of the post consolidation challenges that still on-going.

The total quality management approach outline by Stevenson (2007) supports the fact that TQM is customer focus. This approach is describe as follows: find out what the customer wants; design a product or service that meets or exceeds customer wants; design processes that facilitates doing the job right the first time; keep track of results and extend these concepts to suppliers. Focusing on both internal and external customers' needs or understanding the customers is the driving force behind TQMschemes (Stevenson, 2007).

\subsubsection{Data-Driven Decision Management}

Recent Emphasis on Data-Driven Decision Making (DDDM) has resulted in a vast body of research elucidating the power of DDDM for school, classroom, and student improvement. DDDM refers to systematic collection and use of many forms of data from a variety of sources in order to improve student performance (Choppin, 2002; Marsh, Pane \& Hamilton, 2012). DDDM is more than a system for accountability; at the classroom level, DDDM is a learner-centered teaching tool that supports differentiated instruction by providing information that helps teachers tailor instruction to fit class and individual learning needs (Rallis \& MacMullen, 2010). Thus, a major challenge for data-focused educational reform is the identification and implementation of effective professional development practices that lead to transformed instruction (U.S. Department of Education, Institute of Education Sciences, 2009). However, the chain of inferences from teacher use of data systems, to teacher data analysis, to changed instruction, and to improved student outcomes is currently weak (U.S. Department of Education, Institute of Education Sciences, 2009). Furthermore, research related to the change process associated with teacher adoption of DDDM practices is almost nonexistent.

This study focuses on the pre-mentioned variables as they are the most common variables that are used and related to banks in Jordan to provide superior customer value and meet customer needs.

\subsection{Knowledge Management- Total Quality Management Relationship}

Few researchers recently expressed their interest in the relationship of TQM and KM, but, they have not achieved a consensus toward conceptualizing this relation. These practical studies are the ones conducted by (Molina et al., 2007; Hung et al., 2011; Baker, 2014) considered this relationship related to innovation. According to Molina et al. (2007), performance is the criterion. However, these results have different settings in respect of the nature of the relationship. Hung et al. (2010) showed that TQM is a mediator in the relationship between KM and innovation, while Molina et al. (2007) considered knowledge transfer as a mediator between TQM and performance. However, in respect of the methodical aspect of the mediator concept, the mediator represents the general mechanism by which the focal independent variable is able to influence the dependent variable of interest.

These results assure credibility of the relate literature of the relationship. However, some researchers considered KM as a facilitator to TQM (Barber et al., 2006; Stewart \& Waddell, 2008) other scholars concerned TQMas an antecedent or KM (Lin\& Wu, 2005; Choo et al., 2007; Molina et al., 2007; Colurcio, 2009; Jayawara \& Holt, 2009; Frick, 2014).

The relationship between TQM and KM understood in different ways. From one perspective Km is determined as an activator to TQM. Stewart \& Waddell (2008) mentioned that widening the concept of quality for product and service specifications as a quick response to customer needs, clear the relationship between KM and TQM.

Gaining the knowledge and spreading it brings about a quality culture which creates understandable frame work according to quality programs and KM (Al-Salti \& Hackney, 2011). 
On other hand, there are many approaches supposes that TQM is a supporter for KM. Lin \& Lee (2005) presented ISO 9000 process-based knowledge management system architecture, which support knowledge flow in the organization. Abu-Shanab et al. (2014) in a case study research revealed that TQM practices are facilitators of Knowledge Creation and dissemination. Choo et al. (2007) introduces a conceptual framework based on quality programs and KM. Jayawarana \& Holt (2009) analyzed the relationship between knowledge creation and transformation in the research and development context. Based on their case study research, they concluded that TQM practices improve knowledge creation and transformation. Finally, Molina et al. (2007) examined the relationship between TQM practices and knowledge transformation.

\section{Theoretical Framework}

In this study, the dependent variable is total quality management and the independent variable is knowledge management uses. Figure 1 illustrates the theoretical framework developed for this study.

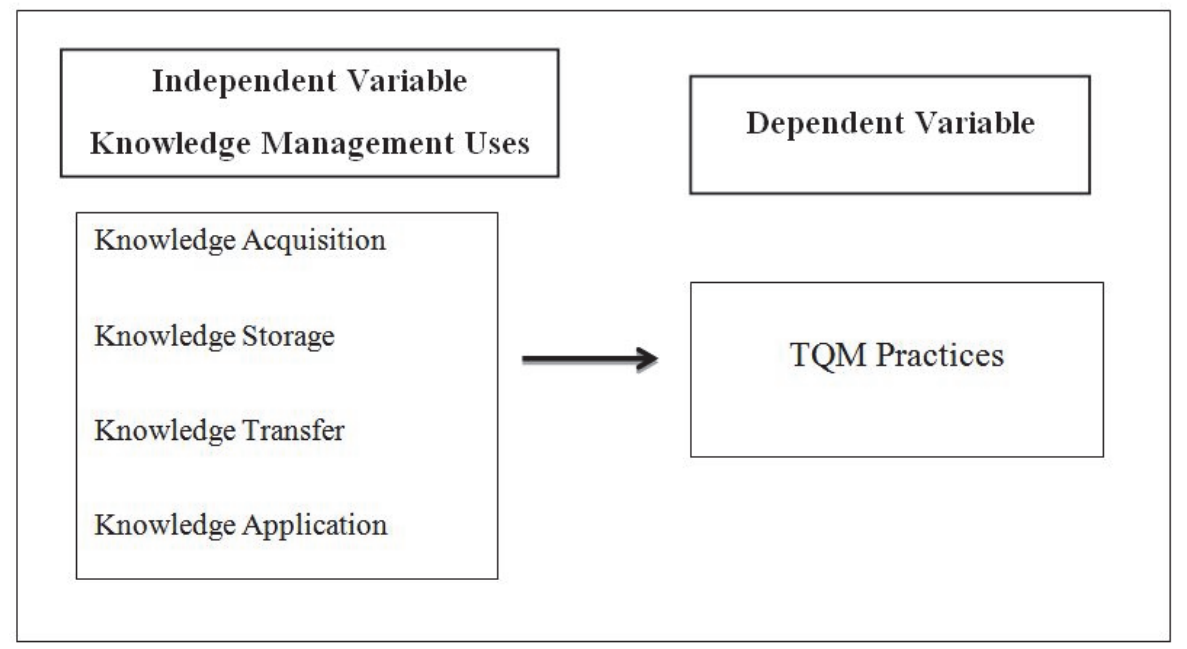

Figure 1. The proposed theoretical framework

\subsection{Operational Definitions of Variables}

\subsubsection{Total Quality Management Practices (Dependent Variable)}

\subsubsection{Top Management Support}

It is the most important critical success factor for project success and it is not simply one of many factors. The finding is justified in the context of the project management literature and the IS factor research on project success. There are implications for practice because it appears that the conventional technical and project management advice has less impact on project success than previously thought. Boards and top managers may have personally accepted that they have more influence on whether a project succeeds or fails. The measure and scale used for top management support can be shown in Appendix 1.

\subsubsection{Employee's Involvement}

One of the greatest underlying factors in the success or failure of any organization is the power of its people, and how well that power is focused towards meeting the organization's objectives. The measure and scale used for Employee's involvement can be shown in Appendix 1.

\subsubsection{Continuous Improvement}

It is an ongoing effort to improve products, services and processes. These efforts can seek incremental improvement over time or breakthrough improvement all at once. Accordingly, the measure and scale used for continuous improvementcan be shown in Appendix 1.

\subsubsection{Customer Focus}

Total Quality Management firms focus on serving the external customers. They should know first the customers' expectations and requirements and then offer the products/services, accordingly. By the aid of successful customer focus efforts, production can be arranged with respect to the customers' needs, expectations, and complaints. This encourages firms to produce high quality and reliable products/services on time with increased efficiency and 
productivity. When customer expectations are met, their satisfaction will increase as well as the firm's sales and market. Accordingly, the measure and scale used for customer focus can be shown in Appendix 1.

\subsubsection{Data-Driven Decision Management (DDDM)}

It is an approach to business governance that values decisions which can be backed up with data and be verified. The data-driven approach is gaining popularity within the enterprise as the amount of available data increases in tandem with market pressures. Accordingly the measure and scale used for Data driven Decision Management can be shown in Appendix 1.

\subsubsection{Knowledge Management (Independent Variable)}

\subsubsection{Knowledge Acquisition}

It is defined as an improved use of existing knowledge and effectively producing new knowledge through active conversation and externalized and distributed as new knowledge. The acquisition and creation of organizational knowledge involves not only the organization knowledge related to the organization's purposes, vision, mission, and principles, but also the sharing and circulating of personal experience. Accordingly, knowledge acquisition is adopted from the work of Bourini et al. (2013) and Girard (2013) and the items used to measure this question can be shown in Appendix 1.

\subsubsection{Knowledge Storage}

It is the process of identifying new knowledge as relevant and important process for current and future use, and storing it in reasonable forms so that anyone in the organization can access it. Accordingly, knowledge storage has been measured using four questionsadopted from the work of Bourini et al. (2013) and Manivannan et al. (2014).

\subsubsection{Knowledge Transfer}

It is critical in Knowledge Management processes. Knowledge transfer describes the business process that distributes and transmits knowledge among individuals or groups who are participating in process activities within or across organizations. Accordingly, knowledge transfer has been measured using four questions adopted from the work of Bourini et al. (2013) and Popli \& Ropian (2014).

\subsubsection{Knowledge Application}

It refers to the processes of applying knowledge to new situations in which users can learn and generate new knowledge and having effective storage and retrieval mechanisms that allow the organization to access that knowledge easily. Accordingly, knowledge application was measured using four items adopted from the work of Bourini et al. (2013).

\subsection{Hypotheses}

In order to test the effect of knowledge management uses on total quality management practices in commercial banks of Jordan, the following hypotheses were developed:

- H1: There is no significant effect of knowledge management uses on total quality management practices in commercial banks in Jordan.

- H1.1: There is no significant effect of knowledge acquisition on total quality management practices in commercial banks in Jordan.

- H1.2: There is no significant effect of Knowledge storage on total quality management practices in commercial banks in Jordan.

- H1.3: There is no significant effect of Knowledge transfer on total quality management practices in commercial banks in Jordan.

- H1.4: There is no significant effect of Knowledge application on total quality management practices in commercial banks in Jordan.

\section{Methodology}

Data were collected using a self-administrated questionnaire using a convenience sampling techniques. More specifically, the questionnaire was distributed to 300 projects stakeholders (directors, project managers, customer service, quality management employees) working in commercial banks Amman/Jordan. 250 completed questionnaires were returned yielding a $70 \%$ response rate. A 5 Likert scale ranging from 1-Strongly disagree to 5-Stongly agree was used to measure the items used in this study.Before the data was collected, the questionnaire has been explained on the arbitrators with a group of jurisdiction of the faculty members from number of professors of the University of Jordan, majoring in business administration, in order to ensure validity of the data collection, and after retrieving the questionnaires, the researchers conducted the proposed amendments of the arbitrators 
before being distributed to a sample study. After that, the questionnaire was also tested with 20 potential respondents to check the questionnaire for content validity and to make sure that the tool that was used in this study actually measure what should be measured. In this study, scale reliability was assessed using Cronbach's alpha coefficient. The internal consistency coefficient should be minimum 0.60 (Hair et al., 2010; Sekaran \& Bougie, 2013). The results in Table 1 show that Cronbach's alpha coefficient range from 0.619 to 0.79 . Therefore, all values are highly reliable since alpha above 0.6 . This result indicates a good internal consistency among the items related to its dimensions, also to each variable, and the entire scale.

Table 1. Reliability of the items used in this study

\begin{tabular}{lll}
\hline Construct & Number of Items & Cronbach's Alpha Values \\
\hline Top Management Support & 3 & 0.703 \\
Employees Involvement & 6 & 0.653 \\
Continuous Improvement & 8 & 0.658 \\
Customer Focus & 4 & 0.619 \\
Data-Driven Decision Management & 3 & 0.756 \\
\hline TQM Practices & 6 & 0.616 \\
\hline Knowledge Acquisition & 5 & 0.684 \\
Knowledge Storage & 4 & 0.66 \\
Knowledge Transfer & 4 & 0.790 \\
Knowledge Application & 0.656 \\
\hline Knowledge Management Practices & & 0.752 \\
\hline
\end{tabular}

\section{Data Analysis and Discussion}

\subsection{Demographic Characteristics of the Respondents}

The data collected through the questionnaire distributed to the employees were analyzed using Statistical Package for Social Science version 21.0. The demographic characteristics of the respondents can be shown in table 2 .

Table 2. The respondents' profile

\begin{tabular}{lll}
\hline Respondent's characteristics & Frequency & Percentages \\
\hline Gender & & \\
\hline Male & 178 & 71.2 \\
Female & 72 & 28.8 \\
\hline Qualification & & \\
\hline Bachelor & 223 & 89.2 \\
Master & 19 & 7.6 \\
PhD & 8 & 3.2 \\
\hline Experience & \\
\hline Lower than 5 years & 146 & 58.4 \\
5 years to lower than 10 years & 72 & 28.8 \\
10 years to lower than 15 years & 18 & 7.2 \\
15 years to lower than 20 years & 7 & 2.8 \\
20 years and above & 7 & 2.8 \\
\hline
\end{tabular}

As can be shown in Table 2, among the 250 usable questionnaires, there was $178(71.2 \%)$ male and $72(28.2 \%)$ female. Furthermore, Table 2also shows that respondents who have bachelor qualification form (89.2\%) and who have a master degree form (7.6\%). Moreover, table 2 reveals that respondents who have experience lower than 5 years form (58.4\%) and people who have 5 years to lower than 10 years experience form (28.8\%). Also, people who have 10 years to lower than 15 years experience form (7.2\%). However, people who have 15 years to lower than 20 years and people who have 20 years and above experience form the same percent (2.8\%). This support that most of the respondents have lower than 5 years experience.

\subsection{Descriptive Analysis}

The descriptive statistics of the constructs used in the proposed research model can be shown Appendix 1. The 
results in Appendix 1 show that the standard deviations ranged from .916 to 1.64 which indicate a narrow spread around the mean. In addition, all means were above the mid-point of 2.5 and most of the variables were classified "high". The results show that the majority of respondents express generally positive answers to the variables used in the research model. This result support that the knowledge management uses and total quality management promote the growth of commercial banks in Jordan and employee satisfaction in the banks affected by the growth of total quality management. More specifically, the results reveal that the Jordanian commercial banks present the TQM concept to their employees and have a sufficient training department for their employees. In addition, it can be noticed that Jordanian banks allow their employees to establish and carry out their job by the methods and means they believe appropriate. Also, the Jordanian banks look to be in the running with the knowledge of modern technology in the field of communication through giving scholarships to their employee. Moreover, the majorities of Jordanian banks encourage their employees to gain more knowledge from the experience of successful international practices and alsoencourages their staffs and workers to participate in the training programs inside and outside Jordan to gain more information in their fields, which in turn lead to enhance the performance

In addition, it shows that the employees in banks have confidence in the relationship between the application of the TQM concept and the accomplishment of the bank. Also, the bank administration shares its staffs in discovering the appropriate results and solutions to the problems that face the department they are working in. The results showed also that the bank management enhanced and established the motivation configuration to suit the TQM concept. Also, the Jordanian bank management inspires and become accustomed to the new ideas. Therefore, the improvement in the Jordanian banks is a continuous process. Furthermore, it can be noticed that Jordanian banks always looking to satisfy their customer needs and has general strategic goals for the quality. Moreover, it can be noticed that Jordanian banks management aims to reduce the cost of different financial procedures and have strategyplan to present the TQM concept to their staffs. Also, the Jordanian bank has a credential system that is appropriatefor allworkers in all levels. Also, Jordanian banks have a database and procedures that aim to make steps that required providing the service, easier. Furthermore, Jordanian commercial banks take a great attention to encourage the innovative ideas and suggestions that provided by their workers.

\subsection{Hypotheses Testing}

In order to examine the study hypotheses the multiple regression analysis was applied. The result of the study hypotheses will be displayed in the table below:

Table 3. The results of the hypotheses testing

\begin{tabular}{lccccccc}
\hline & \multicolumn{3}{c}{ Model summary } & \multicolumn{2}{c}{ ANOVA } & \multicolumn{2}{c}{ Coefficients(a) } \\
\cline { 2 - 7 } & $\mathrm{R}$ & $\mathrm{R}^{2}$ & Adjusted R Square & F-value & Sig & & \\
\cline { 2 - 7 } & .352 & 0.124 & 0.109 & 8.652 & 0.000 & t & Sig. \\
\hline Knowledge Acquisition & & & & & & 2.229 & 0.027 \\
Knowledge Storage & & & & & 3.557 & 0.000 \\
Knowledge Transfer & & & & & 2.245 & 0.026 \\
Knowledge Application & & & & & 0.275 & 0.784 \\
\hline
\end{tabular}

It can be seen from the result in table (3) that the multiple correlation coefficient $\mathrm{R}=0.352$ indicates that there is a positive correlation between total quality management and knowledge management. Also, the value of $\mathrm{R}^{2}=$ 0.124 . This means that the knowledge management can account $(12.4 \%)$ of the variation of the total quality management.It is noticed that the value of adjusted $R^{2}$ is very close to the value of $R^{2}$. If the adjusted $R^{2}$ is excluded from $\mathrm{R}^{2}(0.124-0.109)=0.015$. This little shrinking $(0.015)$ means that if the model has been fitted when the whole population participates in the study, there will be 0.015 less variance in the outcome. The above table also shows the analysis of variance (ANOVA) which is used to statistically test the main hypothesis. It can be seen from the above table that there is a statistical effect of knowledge management on total quality management.

Furthermore, the above table shows that the Knowledge Acquisition has a statistical effect on total quality management at P-value (0.027) and the T calculated (2.229) is higher than the T tabulated (1.96). Also, the table above reveals that the Knowledge Storage has a statistical effect on total quality management at a significant level $(0.05)$, where the P-value is $(0.000)$. Moreover, the results in the above table show that the Knowledge Transfer has a statistical effect on total quality management at P-value (0.026) at a significant level (0.05). Whereas, the above table shows that Knowledge Application has no statistical effect on the total quality management, where the $\mathrm{T}$ calculated (0.275) is lower than the T tabulated (1.96). 
Table 4. Summary of the study hypothesis results

\begin{tabular}{ll}
\hline Study hypothesis & result \\
\hline H1: There is no significant effect of knowledge management uses on total quality management & Rejected \\
practices in commercial banks in Jordan & \\
H1.1: There is no significant effect of knowledge acquisition on total quality management practices & Rejected \\
in commercial banks in Jordan & \\
$\begin{array}{ll}\text { H1.2: There is no significant effect of Knowledge storage on total quality management practices in } \\
\text { commercial banks in Jordan. }\end{array}$ & Rejected \\
$\begin{array}{ll}\text { H1.3: There is no significant effect of Knowledge transfer on total quality management practices in } \\
\text { commercial banks in Jordan }\end{array}$ & Rejected \\
$\begin{array}{ll}\text { H1.4: There is no significant effect of Knowledge application on total quality management practices } \\
\text { in commercial banks in Jordan. }\end{array}$ & $\begin{array}{l}\text { Accepte } \\
\text { d }\end{array}$ \\
\hline
\end{tabular}

As can be shown in Table 4, H1, H1.1, H1.2 and H1.3 were rejected, while H1.4 was accepted.

\section{Discussion, Conclusion and Recommendations}

This study is devoted to identify the knowledge management and to present its role in effect on Total quality management through (Top Management support, Employees involvement, Continuous Improvement, Customer Focus, Data driven Decision Management, Knowledge Storage, Knowledge Application, Knowledge Acquisition, Knowledge Transfer)in enhancing the quality of service at banks and service firms in Jordan. The fundamental statistical analysis was applied in order to achieve the main objective of this study. The following findings are shown below:

The study results reveal that the multiple correlation coefficient $\mathrm{R}=0.352$ indicates that there is a positive correlation between total quality management and knowledge management. This support that the Jordanian commercial banks do create procedure that simplifying knowledge-related events such as transformation and use of knowledge (Bhatt, 2002). Furthermore, the Jordanian commercial banks are in the process of evaluating, storing, and commercializing proficiency of the employees, which in turn make the Jordanian banks more powerful and valuable and more competitive than its competitors (Bollinger \& Smith, 2001). Moreover, the quality management department in the Jordanian banks spent more effort to produce high-qualified products for their customers. This result is consistent with (Honarpour et al., 2012) who examined the relationship between total quality management practices and knowledge management and they found a positive relation between them. Also, this result is in the line with (Ju et al., 2006) who founds that total quality management practices and knowledge management are synergistically related to each other.

Also, the study analysis of variance reveals that knowledge management useshas a statistical effect on total quality management at F-value (8.652). Furthermore, the study results reveal that knowledge acquisition has a statistical effect on total quality management. This support that the Jordanian banks took a great attention to the innovative ideas, thoughts and suggestions proposed by their employees, as the innovation has an important impact on business development and survival. This result is consistent with (Kor \& Maden, 2013) who found that knowledge management processes relate positively to innovation. Also, the study results show that the knowledge storage has a statistical effect on total quality management. This support that the Jordanian banks have an adequate database which is available for their employees and the Jordanian commercial banks encourages their workers to seek new ideas from all possible sources. This result is in the line with (Ju et al., 2006) who found that knowledge storage can reduce the engineers' time and problem-solving skills was further improved.

Moreover, the results show that the knowledge transfer has a statistical effect on total quality management. This indicates that the Jordanian commercial bank management encourages the knowledge exchange among their employees and have an information system facility the knowledge sharing among the workers and staff. This result is consistent with (Molina et al., 2007) who found a positive relationship between the presence of external and internal knowledge transfer and total quality management. Whereas, the results reveal that knowledge application has no statistical effect on the total quality management.

\subsection{Recommendation and Future Studies}

Based on the finding of this study the following recommendations were presented as follows:

Bank sector has shown huge growth in recent years and it's considered one of the most competitive sectors in Jordan; however, its need to invest more in implementing knowledge management in order to manage knowledge created within the organization, this will help them to maintain their competitive position in the changing banking 
sector. The importance for the banking sector to invest more in telecommunication banking technology to perform its service with less time and effort and updated to customer services. The Jordanian commercial banks should demonstrate the importance of the TQM concept to their employees and have a sufficient training department for their employees. Obeidat et al. (2013) found that Jordanian commercial banks should take a great attention for encouraging the innovative ideas and suggestions that provided by their workers. The Jordanian commercial banks should encourage the continuously meeting in order to discuss the issues and work problems, which may increase the performance and enhance the profitability. The Jordanian commercial banks should facilitate and encourage ideas sharing between and among employees.

Also, researchers called for more research on the enabling factors of applying electronic services (e.g. Masa'deh, et al., 2008, 2013a, 2013b; Karajeh \& Maqableh, 2014; Maqableh \& Karajeh, 2014; Al-Dmour et al., 2015; Almajali \& Maqableh, 2015; Kateb et al., 2015; Maqableh et al., 2015; Masa'deh, 2016; Tarhini et al., 2015; 2016, 2017a, 2017b; Almajali \& Al-Dmour, 2016; Almajali et al., 2016; Alenezi et al., 2017; Aldmour et al., 2017; Khwaldeh et al., 2017; Mikkawi \&Al-Lozi, 2017; Yassien \& Mufleh, 2017; Tarhini et al., 2018; Al-Dmour et al., 2019), hence, future research is vital to examine these enablers as to assist stakeholders on their decisions on reaching high levels of such services, and in turn enhancing TQM practices in an optimal way.

\section{References}

Abbasi, M. S., Elyas, T., \& Shah, F. (2015). Impact of individualism and collectivism over the individual's technology acceptance behaviour: A multi-group analysis between Pakistan and Turkey. Journal of Enterprise Information Management, 28(6), 747-768.

Aboyassin, N. A., Alnsour, M., \& Alkloub, M. (2011). Achieving total quality management using knowledge management practices: A field study at the Jordanian insurance sector. International Journal of Commerce and Management, 21(4), 394-409.

Abualoush, S., Bataineh, K., \& Alrowwad, A. (2018a). The role of knowledge management process and intellectual capital as intermediary variables between knowledge management infrastructure and organization performance. Interdisciplinary Journal of Information, Knowledge, and Management, 13, 279-309.

Abualoush, S. H., Obeidat, A. M., Tarhini, A., Masa'deh, R., \& Al-Badi, A. (2018b). The role of employees' empowerment as an intermediary variable between knowledge management and information systems on employees' performance. VINE Journal of Information and Knowledge Management Systems, 48(2), 217-237.

Abu-Shanab, E., Haddad, M., \& Knight, M. B. (2014). Knowledge sharing practices and the learning organization: A study. IUP Journal of Knowledge Management, 12(2), 38-50.

Al Azmi, N., Al-Lozi, M., Al-Zu’bi, Z., \& Dahiyat, S. (2012). Patients attitudes toward service quality and its impact on their satisfaction in physical therapy in KSA hospitals. European Journal of Social Sciences, 34(2), 300-314.

Al-dalahmeh, M., Khalaf, R., \& Obeidat, B. (2018). The effect of employee engagement on organizational performance via the mediating role of job satisfaction: The case of IT employees in Jordanian banking sector. Modern Applied Science, 12(6), 17-43.

Al-Dmour, R, Obeidat, B., \& Almajali, D. (2015). The practice of HRIS applications in business organizations in Jordan: An empirical study. 4th Scientific \& Research Conference on New Trends in Business, Management and Social Sciences (COES\&RJ-TK15/1).

Al-Dmour, R., Al Haj Dawood, E., Al-Dmour, H., \& Masa'deh, R. (2019). The effect of customer lifestyle patterns on the use of mobile banking applications in Jordan. Int. J. Electronic Marketing and Retailing, Forthcoming.

Aldmour, R., Masa'deh, R., \& Obeidat, B. (2017). Factors influencing the adoption and implementation of HRIS applications: Are they similar. International Journal of Business Innovation and Research, 14(2), 139-167.

Alenezi, H., Tarhini, A., Alalwan, A., \& Al-Qirim, N. (2017). Factors affecting the adoption of e-government in Kuwait: A qualitative study. Electronic Journal of e-Government, 15(2), 84-102.

AlHarrasi, J., \& AL-Lozi, M. (2015). The role of innovation management and technological innovation on organizational effectiveness. 4th Scientific \& Research Conference on New Trends in Business, Management and Social Sciences (COES\&RJ-TK15/1), Istanbul, Turkey.

AlHrassi, J., Al-Lozi, M., \& Irtaimeh, H. (2016). The impact of management innovation and technological 
innovation on organizational effectiveness: An empirical study from managerial staff perspective in Sultan Qaboos University. Journal of Social Sciences (COES\&RJ-JSS), 5(3), 309-339.

Alkandari, A., Masa'deh, R., \& Al-Lozi, M. (2017). Knowledge management and its role on organizational crisis management: A literature review. Journal of Social Sciences (COES\&RJ-JSS), 6(4), 833-850.

Almajali, D., \& Al-Dmour, R. (2016). The role of information technology in motivating students to accept elearning adoption in universities: A case study in Jordanian universities. Journal of Business \& Management (COES\&RJ-JBM), 4(1), 36-46.

Almajali, D., \& Maqableh, M. (2015). Assessing the digital divide status of the Jordanian telecentre. International Journal of Communications, Network and System Sciences, 8(11), 428-439.

Almajali, D., Masa'deh, R., \& Al-Lozi, M. (2016). Determinants of the actual use of e-learning systems: An empirical study on Zarqa University in Jordan. Journal of Social Sciences (COES\&RJ-JSS), 5(2), 172-200.

Al-Salti, Z., \& Hackney, R. (2011). Factors impacting knowledge transfer success in information systems outsourcing. Journal of Enterprise Information Management, 24(5), 455-468.

Al-Syaidh, N., \& Al-Zu'bi, Z. (2014). Transformational leadership and its impact on the effectiveness of employees' behavior in the public and private Jordanian hospitals. Jordan Journal of Business Administration, $11(1), 23-57$.

AL-Syaidh, N., Al- Lozi, M., \& AlHarrasi, J. (2016). Transformational leadership and its role on the effectiveness of employees' behavior: A theoretical study. Journal of Business \& Management (COES\&RJ-JBM), 4(1), 1435.

Baker, M. J. (2014). Marketing Strategy and Management (2nd Ed). Macmillan Basingstoke.

Banabo, E., Ndiomu, K., \& Koroye, B. H. (2011). Customer service strategies of retail organizations in the Niger Delta area of Nigeria. Asian Journal of Business Management, 3(3), 219-227.

Barber, K. D., Munive-Hernandez, J. E., \& Keane, J. P. (2006). Process-based knowledge management system for continuous improvement. International Journal of Quality \& Reliability Management, 23(8), 1002-1018.

Bhatt, G. D. (2002). Management strategies for individual knowledge and organizational knowledge. Journal of Knowledge Management, 6(1), 31-39.

Bhuiyan, N., \& Baghel, A. (2005). An overview of continuous improvement: From the past to the present. Management Decision, 43(5), 761-771.

Bollinger, A. S., \& Smith, R. D. (2001). Managing organizational knowledge as a strategic asset. Journal of Knowledge Management, 5(1), 8-18.

Bourini, F., Khawaldeh, K., \& Shaker, A. (2013). The role of knowledge management in banks sector (analytical study-Jordan). Interdisciplinary Journal of Contemporary Research in Business, 5(3), 53-77.

Choo, A. S., Linderman, K. W., \& Schroeder, R. G. (2007). Method and context perspectives on learning and knowledge creation in quality management. Journal of Operations Management, 25(4), 918-931.

Choo, C., \& Bontis, N. (2007). The strategic management of intellectual capital and organization knowledge. New York: Oxford University Press.

Choppin, J. (2002, April). Data use in practice: Examples from the school level. In Annual Meeting of the American Educational Research Association, New Orleans, LA.

Colurcio, M. (2009). TQM: A knowledge enabler?. The TQM Journal, 21(3), 236-248.

Cummings, J. L. (2002). Knowledge transfer across $R \& D$ units: an empirical investigation of the factors affecting successful knowledge transfer across intra-and inter-organizational units. Unpublished doctoral dissertation, George Washington University.

Curry, A., \& Kkolou, E. (2004). Evaluating CRM to contribute to TQM improvement: A cross-case comparison. The TQM Magazine, 16(2), 314-324.

Danish, R., Asghar, A., \& Asghar, S. (2014). Factors of knowledge management in banking sector of Pakistan. Journal of Management Information System and E-commerce, 1(1), 41-49.

Darawsheh, S., ALshaar, A., \& AL-Lozi, M. (2016). The degree of heads of departments at the University of Dammam to practice transformational leadership style from the point of view of the faculty members. Journal of Social Sciences (COES\&RJ-JSS), 5(1), 56-79. 
Deming, W. E. (2005). Out of the Crisis. MIT Center for Advanced Engineering. Cambridge:MA, University Press.

Ford, D. P., \& Staples, S. (2010). Are full and partial knowledge sharing the same?. Journal of Knowledge Management, 14(3), 394-409.

Fotopoulos, C. V., \& Psomas, E. L. (2010). The structural relationships between TQM factors and organizational performance. The TQM Journal, 22(5), 539-552.

Frey, A. (2001). Happiness, economy and institutions. The Economic Journal, 110(4), 918-938.

Frick, W. (2014). An introduction to data-driven decisions for managers who don't like math. Harvard Business Review, May, 19, 1-6.

Girard, J. (2015). Defining knowledge management: Toward an applied compendium. Online Journal of Applied Knowledge Management, 3(1), 1-20.

Gold, A. H., Malhotra, A, \& Segars, A. (2011). Knowledge management: An organizational capabilities perspective. Journal of Management Information Systems, 18(1), 185-214.

Gupta, B., Iyer, L. S., \& Aronson, J. E. (2000). Knowledge management: Practices and challenges. Industrial Management \& Data Systems, 100(1), 17-21.

Hair, J. F., Anderson, R. E., Tatham, R. L., \& Black, W. C. (2010). Multivariate data analysis (7th ed.). New Jersey: Prentice Hall.

Hajir, J. A., Obeidat, B. Y., \& Al-Dalahmeh, M. A. (2015). The role of knowledge management infrastructure in enhancing innovation at mobile telecommunication companies in Jordan. European Journal of Social Sciences, 50(3), 313-330.

Hales, T. C. (2010). Cannonballs and honeycombs. Notices-American Mathematical Society, 57(4), 440-449.

Honarpour, A., Jusoh, A., \& Md Nor, K. (2012). Knowledge management, total quality management and innovation: A new look. Journal of technology management \& innovation, 7(3), 22-31.

Hung, R.Y., Lien, B. Y., Fang, S. C., \& McLean, G. N. (2010). Knowledge as a facilitator for enhancing innovation performance through total quality management. Total Quality Management, 21(4), 425-438.

Hung, R. Y., Lien, B. Y., Yang, B., Wu, C. M., \& Kuo, Y. M. (2011). Impact of TQM and organizational learning on innovation performance in the high-tech industry. International Business Review, 20(2), 213-225.

Ju, T. L., Lin, B., Lin, C., \& Kuo, H. J. (2006). TQM critical factors and KM value chain activities. Total Quality Management \& Business Excellence, 17(3), 373-393.

Juergensen, T. (2005). Continuous improvement: Mindsets, capability, process, tools and results. The Juergensen Consulting Group, Inc., Indianapolis, IN.

Karajeh, H., \& Maqableh, M. (2014). Security of cloud computing environment. The 23rd IBIMA Conference on Vision 2020: Sustainable Growth, Economic Development, and Global Competitiveness, USA, 2202-2215.

Kateb, M., Swies, R., Obeidat, B., \& Maqableh, M. (2015). An investigation on the critical factors of information system implementation in Jordanian information technology companies. European Journal of Business and Management, 7(36), 11-28.

Khalayleh, W., Masa'deh, R., \& Al-Lozi, M. (2017). Administrative empowerment and its role on the work teams Performance: A literature review. Journal of Social Sciences (COES\&RJ-JSS), 6(4), 851-868.

Khwaldeh, S., Al-Hadid, I., Masa'deh, R., \& Alrowwad, A. (2017). The association between e-services web portals information quality and ICT competence in the Jordanian universities. Asian Social Science, 13(3), 156-169.

Krogh, G., \& Roos, J. (1995). Conversation management. European Management Journal, 13(4), 390-394.

Lawson, S. (2013). Examining the relationship between organizational culture and knowledge management. Unpublished doctoral dissertation, Nova Southern University.

Lin, C., \& Wu, C. (2005). Managing knowledge contributed by ISO 9001: 2000. International Journal of Quality $\&$ Reliability Management, 22(9), 968-985.

Lin, H. F., \& Lee, G. G. (2005). Impact of organizational learning and knowledge management factors on ebusiness adoption. Management Decision, 43(2), 171-188.

Manivannan, M., Kathiravan, C., \& Deepak, R. (2014). Employees perspective of knowledge management in banks. Indian Streams Research Journal, 4(9), 22-37. 
Maqableh, M., \& Karajeh, H. (2014). Job scheduling for cloud computing using neural networks. Communications and Network, 6(3), 191-200.

Maqableh, M., Rajab, L., Quteshat, W., Khatib, T., \& Karajeh, H. (2015). The impact of social media networks websites usage on students' academic performance. Communications and Network, 7(4), 159-171.

Marsh, J. A., Pane, J. F., \& Hamilton, L. S. (2012). Making sense of data-driven decision making in education. Santa Monica, CA: RAND Corporation.

Masa'deh, R. (2016). The role of knowledge management infrastructure in enhancing job satisfaction at Aqaba five star hotels in Jordan. Communications and Network, 8(4), 219-240.

Masa'deh, R., Alrowwad, A., Alkhalafat, F., Obeidat, O., \& Abualoush, S. (2018). The role of corporate social responsibility in enhancing firm performance from the perspective of IT employees in Jordanian banking sector: The mediating effect of transformational leadership. Modern Applied Science, 12(7), 1-26.

Masa'deh, R., Gharaibeh, A., Maqableh, M., \& Karajeh, H. (2013a). An empirical study of antecedents and outcomes of knowledge sharing capability in Jordanian telecommunication firms: A structural equation modeling approach. Life Science Journal, 10(4), 2284-2296.

Masa'deh, R., Gharaibeh, A., Tarhini, A., \& Obeidat, B. (2015a). Knowledge sharing capability: A literature review. 4th Scientific \& Research Conference on New Trends in Business, Management and Social Sciences (COES\&RJ-TK15/1), Istanbul, Turkey.

Masa'deh, R., Hunaiti, Z., \& Bani Yaseen, A. (2008). An integrative model linking IT-business strategic alignment and firm performance: The mediating role of pursuing innovation and knowledge management strategies. Communications of the International Business Information Management Association (IBIMA) Journal.

Masa'deh, R., Obeidat, B., Al-Dmour, R., \& Tarhini, A. (2015b). Knowledge management strategies as intermediary variables between IT-business strategic alignment and firm performance. European Scientific Journal, 11(7), 344-368.

Masa'deh, R., Obeidat, B., Zyod, D., \& Gharaibeh, A. (2015c). The associations among transformational leadership, transactional leadership, knowledge sharing, job performance, and firm performance: A theoretical model. Journal of Social Sciences (COES\&RJ-JSS), 4(2), 848-866.

Masa'deh, R., Shannak, R., \& Maqableh, M. (2013b). A structural equation modeling approach for determining antecedents and outcomes of students' attitude toward mobile commerce adoption. Life Science Journal, 10(4), 2321-2333.

Mikkawi, B., \& Al-Lozi, M. (2017). The impact of knowledge management infrastructure on academic staff effectiveness: An empirical study at The University of Jordan. Jordan Journal of Business Administration, 13(1), 95-127.

Molina, L. M., Lloréns-Montes, J., \& Ruiz-Moreno, A. (2007). Relationship between quality management practices and knowledge transfer. Journal of Operations Management, 25(3), 682-701.

Mondy, R. W. (2013). Human resource management (10th ed.). Boston: Pearson.

Montes, F. J., Ruiz Moreno, A., \& Miguel Molina, L. (2003). An analysis of the relationship between quality and perceived innovation: "the case of financial firms". Industrial Management \& Data Systems, 103(8), 579590.

Nonaka, I., \& Takeuchi, H. (2015). The knowledge-creating company, Oxford University Press.

Oakland, J. (2007). TQM "Text with cases". Butterworth-Heinemann.

Obeidat, B., El-Rimawi, S., Maqableh, M., \& Al-Jarrah, I. (2013). Evaluating the profitability of the Islamic banks in Jordan. European Journal of Economics, Finance and Administrative Sciences, 56, $27-36$.

Obeidat, B., Sweis, R., Zyod, D., \& Alshurideh, M. (2012). The effect of perceived service quality on customer loyalty in internet service providers in Jordan. Journal of Management Research, 4(4), 224-242.

Obeidat, B., Tarhini, A., \& Aqqad, N. (2017). The impact of intellectual capital on innovation via the mediating role of knowledge management: A structural equation modeling approach. International Journal of Knowledge Management Studies, 8(3/4), 273-298.

Pacharapha, T., \& Vathanophas, V. (2012). Knowledge acquisition: The roles of perceived value of knowledge content and source. Journal of Knowledge Management, 16(5), 724-739. 
Popli, G. S., \& Ropian, P. (2014). Adoption of quality circles approach a powerful tool for quality improvement in the working of commercial banks in India. Delhi School of Business, October, 2014.

Rallis, S. F., \& MacMullen, M. M. (2010). Inquiry-minded schools: Opening doors for accountability. Phi Delta Kappan, 81(10), 766.

Sekaran, U., \& Bougie, R. (2013). Research methods for business: A skill-building approach. (6th edition), New York: Wiley.

Shannak, R., \& Obeidat, B. (2012). Culture and the implementation process of strategic decisions in Jordan. Journal of Management Research, 4(4), 257-281.

Stein, E. W., \&Zwass, V. (2005). Actualizing organizational memory with information systems. Information Systems Research, 16(2), 85-117.

Stevenson, J. W. (2007). Operations Management. 9th ed. McGraw-Hill, New York: USA.

Stewart, D., \& Waddell, D. (2008). Knowledge management: The fundamental component for delivery of quality. Total Quality Management, 19(9), 987-996.

Su, C. H., Tsai, A., \& Hsu, C. L. (2010). The TQM extension: Total customer relationship management. Total Quality Management, 21(1), 79-92.

Sweis, R. J., Al-Mansour, A., Tarawneh, M., \& Al-Dweik, G. (2013). The impact of total quality management practices on employee empowerment in the healthcare sector in Saudi Arabia: a study of King Khalid Hospital. International Journal of Productivity and Quality Management, 12(3), 271-286.

Tarhini, A., Alalwan, A., Al-Qirim, N., \&Algharabat, R. (2018). An analysis of the factors influencing the adoption of online shopping. International Journal of Technology Diffusion (IJTD), 9(3), 68-87.

Tarhini, A., Al-Badi, A., Almajali, M., \& Alrabayaah, S. (2017a). Factors influencing employees' intention to use cloud computing. Journal of Management and Strategy, 8(2), 47.

Tarhini, A., Al-Busaidi, K., Bany Mohammed, A., \& Maqableh, M. (2017b). Factors influencing students' adoption of e-learning: A structural equation modeling approach. Journal of International Education in Business, 10(2), 164-182.

Tarhini, A., Bany Mohammed, A., \& Maqableh, M. (2016). Modeling factors affecting student's usage behaviour of e-learning systems in Lebanon. International Journal of Business and Management, 11(2), 299.

Tarhini, A., Mgbemena, C., \& Trab, M. S. A. (2015). User adoption of online banking in Nigeria: A qualitative study. Journal of Internet Banking and Commerce, 20(3), 1-8.

Wang, C. H., Chen, K. Y., \& Chen, S. C. (2012). Total quality management, market orientation and hotel performance: The moderating effects of external environmental factors. International Journal of Hospitality Management, 31(1), 119-129.

Wiig, K. M. (2007). Knowledge management: An introduction and perspective. Journal of Knowledge Management, 11(1), 6-14.

Yassien, E., \& Mufleh, M. (2017). The impact of ERP system's usability on enterprise resource planning project implementation success via the mediating role of user satisfaction. Journal of Management Research, 9(3), 49-71.

Young, R. (2013). Knowledge management for the public sector. Tokyo, Japan: Asian Productivity Organziation.

Young, R., \& Jordan, E. (2008). Top management support: Mantra or necessity?. International Journal of Project Management, 26(7), 713-725.

\section{Appendix 1.}

Table A1. Means and Standard Deviation for the Constructs used in the Conceptual Model

\begin{tabular}{llll}
\hline Top Management Support & Mean & STD & Level \\
\hline $\begin{array}{l}\text { The management introduces the TQM concept to their employees. } \\
\text { The management distribute a book about quality on their employees explain } \\
\text { the service quality improvement steps. }\end{array}$ & 3.84 & 0.989 & High \\
$\begin{array}{l}\text { The bank has a training department (provided with annual budget and } \\
\text { equipment needed for training). }\end{array}$ & 3.86 & 0.994 & High \\
\hline
\end{tabular}




\begin{tabular}{|c|c|c|c|}
\hline Total & 3.85 & 0.989 & High \\
\hline Employees Involvement & Mean & STD & Level \\
\hline $\begin{array}{l}\text { The bank employees believe in the relationship between the application of } \\
\text { the TQM concept and the success of the bank. }\end{array}$ & 3.82 & 0.917 & High \\
\hline Training programs includes employees from all management levels. & 3.95 & 0.915 & High \\
\hline $\begin{array}{l}\text { The bank management share its employees in finding the suitable solutions } \\
\text { to the problems that face the department they are working in. }\end{array}$ & 4.06 & 0.871 & High \\
\hline $\begin{array}{l}\text { The employees have the chance to demonstrate their opinions about the jobs they } \\
\text { are doing. }\end{array}$ & 3.69 & 1.028 & High \\
\hline $\begin{array}{l}\text { The bank management forms teams work to improve the bank quality } \\
\text { involving employees in all levels. }\end{array}$ & 3.88 & 0.913 & High \\
\hline $\begin{array}{l}\text { The bank management grants awards to their employees about their excellent } \\
\text { performance. }\end{array}$ & 3.85 & 0.935 & High \\
\hline Total & 3.88 & 0.963 & High \\
\hline Continuous Improvement & Mean & STD & Level \\
\hline $\begin{array}{l}\text { The management improved and developed the motivation structure to suit the } \\
\text { TQM concept. }\end{array}$ & 3.64 & 1.089 & Medium \\
\hline $\begin{array}{l}\text { The training programs aims to minimize the mistakes and achieving high level } \\
\text { of quality. }\end{array}$ & 3.76 & 1.06 & High \\
\hline The bank management encourages and adapts wise ideas. & 3.86 & 0.936 & High \\
\hline $\begin{array}{l}\text { The bank has teams work that meet continuously to discuss the work } \\
\text { problems and make decisions. }\end{array}$ & 3.41 & 1.11 & Medium \\
\hline $\begin{array}{l}\text { The bank management and its employees are making preventive and } \\
\text { immediate corrective actions for them is takes. }\end{array}$ & 3.57 & 1.167 & Medium \\
\hline $\begin{array}{l}\text { The bank management studies the situation of the other competitors to improve } \\
\text { the service. }\end{array}$ & 3.75 & 1.047 & High \\
\hline The bank has a system to study the market and the economic changes. & 3.6 & 0.953 & Medium \\
\hline The ser & 3.7 & 0.852 & High \\
\hline Total & 3.66 & 1.02 & Medium \\
\hline Customer Focus & Mean & STD & Level \\
\hline $\begin{array}{l}\text { The bank management listens to the customer complaints and provides an } \\
\text { immediate solution. }\end{array}$ & 3.6 & 1.029 & Medium \\
\hline $\begin{array}{l}\text { The bank management makes surveys to know the customer needs and } \\
\text { wants. }\end{array}$ & 3.51 & 1.061 & Medium \\
\hline $\begin{array}{l}\text { There is an active communication method between customers and } \\
\text { employees. }\end{array}$ & 3.76 & 0.967 & High \\
\hline $\begin{array}{l}\text { The bank management has general strategic goals for the quality dependent } \\
\text { on the wants and needs of depositor, loan, and beneficiary. }\end{array}$ & 3.24 & 1.176 & Medium \\
\hline Total & 3.53 & 1.025 & Medium \\
\hline Data-Driven Decision Management & Mean & STD & Level \\
\hline $\begin{array}{l}\text { The management reengineered the organizational structure to suit the TQM } \\
\text { concept. }\end{array}$ & 3.46 & 1.127 & Medium \\
\hline $\begin{array}{l}\text { The management has a completely plan to introduce the TQM concept to } \\
\text { their employees. }\end{array}$ & 3.56 & 1.164 & Medium \\
\hline The management aim to minimize the cost of different financial processes. & 3.64 & 1.139 & Medium \\
\hline Total & 3.55 & 1.138 & Medium \\
\hline Knowledge Acquis & Mean & STD & Level \\
\hline $\begin{array}{l}\text { The bank has a documentation system that is introduced to and applicable } \\
\text { from employees in all levels. }\end{array}$ & 3.5 & 1.076 & Medium \\
\hline The bank has a program to simplify the steps required to provide the service. & 3.56 & 1.041 & Medium \\
\hline $\begin{array}{l}\text { The bank has a program to eliminate the unnecessary activities and training } \\
\text { work. }\end{array}$ & 3.32 & 1.053 & Medium \\
\hline $\begin{array}{l}\text { My Bank concerns with new ideas, thoughts and suggestions proposed by } \\
\text { employees. }\end{array}$ & 3.16 & 43 & $\mathrm{Me}$ \\
\hline My B & 3. & 1.225 & $\mathrm{Mec}$ \\
\hline My Bank encourages collective work and subordinates coop & 3.24 & 1.376 & Medium \\
\hline
\end{tabular}


of competition.

\begin{tabular}{|c|c|c|c|}
\hline Total & 3.33 & 1.232 & Medium \\
\hline Knowledge Storage & Mean & STD & Level \\
\hline $\begin{array}{l}\text { My Bank encourages employees to seek new ideas from all possible sources } \\
\text { (i.e. Internally and Externally). }\end{array}$ & 3.48 & 1.196 & Medium \\
\hline $\begin{array}{l}\text { In my Bank, each department determines important knowledge in its field } \\
\text { to be distributed and exchanged between personnel. }\end{array}$ & 2.4 & 1.464 & Medium \\
\hline $\begin{array}{l}\text { When new knowledge is created, my Bank filters (adjust) it to be suitable } \\
\text { for work environment. }\end{array}$ & 3.49 & 1.29 & Medium \\
\hline $\begin{array}{l}\text { My Bank has a comprehensive, adequate database or(knowledge base) } \\
\text { which is available for all personnel. }\end{array}$ & 3.55 & 1.212 & Medium \\
\hline $\begin{array}{l}\text { My Bank documents new acquired knowledge for each accomplished } \\
\text { project. }\end{array}$ & 3.27 & 1.247 & Medium \\
\hline Total & 3.24 & 1.251 & Medium \\
\hline Knowledge Transfer & Mean & STD & Level \\
\hline $\begin{array}{l}\text { My Bank's information system facilitates ideas sharing between or among } \\
\text { employees to achieve innovation. }\end{array}$ & 3.30 & 1.008 & Medium \\
\hline $\begin{array}{l}\text { My Bank is concerned in participating in conferences and workshops inside } \\
\text { and outside Jordan as a method of obtaining knowledge. }\end{array}$ & 3.36 & 1.048 & Medium \\
\hline $\begin{array}{l}\text { My Bank encourages personnel to join training programs inside and outside } \\
\text { Jordan to gain knowledge in their fields. }\end{array}$ & 3.58 & 1.054 & Medium \\
\hline $\begin{array}{l}\text { My company filters obtained knowledge and determines the most important } \\
\text { part to be distributed and exchanged between personnel. }\end{array}$ & 3.36 & 1.040 & Medium \\
\hline Total & 3.40 & 1.014 & Medium \\
\hline Knowledge Application & Mean & STD & Level \\
\hline $\begin{array}{l}\text { My Bank gives its employees the freedom to organize and carry out their } \\
\text { job by methods and means they believe appropriate. }\end{array}$ & 3.46 & 0.903 & Medium \\
\hline $\begin{array}{l}\text { My Bank has a strong commitment to new ideas because of its important } \\
\text { role in achieving innovation. }\end{array}$ & 3.56 & 1.037 & Medium \\
\hline $\begin{array}{l}\text { My Bank seeks to qualify its personnel through scholarships award to gain } \\
\text { knowledge of modern technology in the field of communication. }\end{array}$ & 3.32 & 0.988 & Medium \\
\hline $\begin{array}{l}\text { My Bank encourages personnel to benefit from the experience of successful } \\
\text { international practices and knowledge to adopt them. }\end{array}$ & 3.29 & 1.051 & High \\
\hline Total & 3.66 & 0.925 & Medium \\
\hline
\end{tabular}

\section{Copyrights}

Copyright for this article is retained by the author(s), with first publication rights granted to the journal.

This is an open-access article distributed under the terms and conditions of the Creative Commons Attribution license (http://creativecommons.org/licenses/by/4.0/). 